\title{
Efek pemberian Chlorophyllin terhadap kadar nitric oxide dan malondialdehida tikus hiperkolesterolemia
}

\author{
Galeh S. Pontang ${ }^{1}$, Andrew Johan ${ }^{2}$, Hertanto W. Subagio ${ }^{1}$
}

\begin{abstract}
Background : Endothelial dysfunction is well-known as an early stage of atherosclerosis. Increased oxidative stress in hypercholesterolemia triggers endothelial dysfunction that is characterized by decreased biological availability of nitric oxide (NO). Experimental studies showed that chlorophyllin had an effective antioxidant activity.

Objectives : To determine the effect of chlorophyllin on nitric oxide (NO) and malondialdehyde (MDA) level of hypercholesterolemic rats.

Methods : Post test only randomized control group used twenty four male Sprague Dawley rats were randomly divided into four groups: without treatment (technical control/K1), hypercholesterolemic (negative control/K2), hypercholesterolemic with chlorophyllin at dose of $1,8 \mathrm{mg} / 200 \mathrm{~g} / \mathrm{d}(\mathrm{Pl})$ and hypercholesterolemic with chlorophyllin at dose of 3,34 $\mathrm{mg} / 200 \mathrm{~g} / \mathrm{d}(\mathrm{P} 2)$. Chlorophyllin was dissolved in water and was given via nasogastric tube for 21 days after the rats got hypercholesterolemia. Total cholesterol level of blood was measured by CHOD-PAP method, level of NO plasma was measured by Griess reaction and level of MDA plasma was measured by TBARS method. Hypothesis test was analyzed by One Way Anova continued by Post hoc LSD test and Kruskall Wallis by significant level of 0,05.

Results :NO plasma level was the lowest in group P2 $(0.203 \pm 0.015 \mu M)$ and the highest in the group K2 $(0,224 \pm 0,001 \mu M)$, but no difference of NO plasma level among groups $(p=0.118)$. There were differences in MDA plasma level among the groups $(p=0.001)$. P1 and P2 groups had lower MDA plasma level than K2 $(2.40 \pm 0.11 \mathrm{nmol} / \mathrm{ml})$, indicated by $(1.94 \pm 0.07$ $\mathrm{nmol} / \mathrm{ml}, \quad \mathrm{p}=0.0001)$ and $(1,37 \pm 0.13 \mathrm{nmol} / \mathrm{ml}, \quad \mathrm{p}=0.0001) \mathrm{respectively,} \mathrm{but} \mathrm{still} \mathrm{higher} \mathrm{than} \mathrm{K1}(0.94 \pm 0.05 \mathrm{nmol} / \mathrm{ml}$, $p=0.0001)$.
\end{abstract}

Conclusion : The treatment of chlrophyllin does not have an effect of NO plasma level, but gives an effect of lower MDA plasma level.

Keywords: chlorophyllin, nitric oxide,malondialdehyde, hypercholesterolemia

\begin{abstract}
ABSTRAK
Latar Belakang: Disfungsi endotel dikenal sebagai tahap awal dari aterosklerosis. Peningkatan stres oksidatif pada hiperkolesterolemia memicu disfungsi endotel yang ditandai dengan penurunan ketersediaan biologis oksida nitrat (NO). Studi eksperimental menunjukkan bahwa klorofilin memiliki aktivitas antioksidan yang efektif.

Tujuan: Mengetahui pengaruh klorofilin pada oksida nitrat (NO) dan malondialdehid (MDA) tingkat tikus hiperkolesterolemia.

Metode: Penelitian eksperimen dengan rancangan post test only dilakukan terhadap 24 ekor tikus Sprague Dawley secara acak dibagi menjadi empat kelompok: tanpa pengobatan (kontrol teknis / K1), hiperkolesterolemia (kontrol negatif / K2), hiperkolesterolemia dengan klorofilin pada dosis 1,8 mg / $200 \mathrm{~g} / \mathrm{d}(\mathrm{Pl})$ dan hiperkolesterolemia dengan klorofilin pada dosis 3,34 mg / 200g / d (P2). Klorofilin dilarutkan dalam air dan diberi melalui pipa nasogastrik selama 21 hari setelah tikus mendapat hiperkolesterolemia. Kadar kolesterol total darah diukur dengan metode CHOD-PAP, tingkat NO plasma diukur dengan reaksi Griess dan tingkat MDA plasma diukur dengan metode TBARS. Uji hipotesis dianalisis dengan One Way Anova dilanjutkan dengan Post hoc LSD tes dan Kruskall Wallis pada tingkat signifikan 0,05.

Hasil: Kadar NO plasma yang terendah pada kelompok P2 $(0,203+0,015 \mathrm{M})$ dan tertinggi pada kelompok K2 (0.224 \pm 0.001 $M)$, tetapi tidak ada perbedaan tingkat NO plasma antar kelompok $(p=0,118)$. Ada perbedaan plasma MDA antar kelompok $(p=0,001)$. P1 dan P2 kelompok plasma MDA lebih rendah dibanding dengan $K 2(2,40+0,11 \mathrm{nmol} / \mathrm{ml})$, ditandai dengan $(1,940,07 \mathrm{nmol} / \mathrm{ml}, \mathrm{p}=0,0001)$ dan (1,37 0,13 nmol / ml, $p=0,0001)$. Kadar MDA kelompok K1 lebih tinggi (0,94 + 0,05 $\mathrm{nmol} / \mathrm{ml}, \mathrm{p}=0,0001)$.
\end{abstract}

Simpulan: pengobatan chlrophyllin tidak memiliki efek pada tingkat NO plasma, tetapi memberikan efek penurunan plasma MDA.

Kata kunci: klorofilin, oksida nitrat, malondialdehid, hiperkolesterolemia

\section{PENDAHULUAN}

${ }^{1}$ Program Studi Gizi, Sekolah Tinggi Kesehatan Ngudi
Waluyo, Indonesia
${ }^{2}$ Fakultas Kedokteran Universitas Diponegoro, Indonesia
Hiperkolesterolemia merupakan salah satu faktor risiko terjadinya aterosklerosis yang prosesnya diawali dengan adanya disfungsi endotel. ${ }^{1,2}$ Aterosklerosis telah diketahui sebagai indikator penyakit kardiovaskuler yang merupakan penyebab utama kesakitan dan kematian di seluruh dunia. 
Disfungsi endotel ditandai adanya hilangnya keseimbangan fungsi atau penurunan ketersediaan biologis nitric oxide (NO). NO dikenal sebagai endothelium-derived relaxing factors (EDRF) yang memiliki peran penting dalam menjaga homeostasis vaskuler. ${ }^{3}$ NO memegang peranan penting dalam regulasi homeostasis vaskuler yaitu menjaga keseimbangan mekanisme vasokonstriksi dan vasodilatasi, mencegah dan menstimulasi proliferasi dan migrasi sel otot polos, serta trombogenesis dan fibrinolisis. $^{4}$

Penurunan kadar NO plasma ditemukan pada pasien dengan hiperkolesterolemia yang disebabkan adanya peningkatan stres oksidatif yang kemudian memicu gangguan jalur dari endothelium Nitric Oxide Synthase (eNOS). ${ }^{5}$ Gangguan yang diakibatkan antara lain yaitu penurunan aktivitas dan ekspresi eNOS, penurunan sensitivitas NO dan peningkatan degradasi NO yang berikatan dengan superoksida $\left(\mathrm{O}_{2}^{-}\right)$menjadi senyawa reaktif peroksinitrit $\left(\mathrm{ONOO}^{-}\right)$(Kawasima, 2004). ${ }^{6}$ Peroksinitrit juga merupakan oksidan yang potensial dalam meningkatkan oksidasi lipid, khususnya Low Density Lypoprotein (LDL).

Peningkatan stres oksidatif pada hiperkolesterolemia memicu terjadinya peroksidasi lipid. Peroksidasi lipid yang tidak terkendali berefek langsung pada kerusakan membran sel dan mengawali berbagai penyakit seperti jantung koroner, stroke, diabetes mellitus, penuaan dan lain-lain (Utami, 2010). ${ }^{7}$ Salah satu indikator yang sering digunakan untuk mengetahui adanya peroksidasi lipid dalam tubuh adalah kadar malondialdehyde (MDA) plasma. ${ }^{8}$

Antioksidan diketahui bermanfaat untuk mengatasi adanya stres oksidatif. Pengaruh antioksidan terhadap fungsi endotel antara lain quercetin yang memacu peningkatan ketersediaan biologis eNOS pada diabetes mellitus dan puerarin yang dapat memperbaiki ekspresi eNOS dan menurunkan indeks aterogenik pada tikus hiperkolesterolemia. ${ }^{9}$

Klorofilin merupakan turunan dari klorofil yang larut air dan mengandung ikatan garam $\mathrm{Na}-\mathrm{Cu}$ bersifat lebih stabil dari klorofil. Salah satu manfaat klorofilin sebagai antioksidan yang efektif, khususnya dalam mengikat oksidan seperti $\mathrm{OH}^{-}$dan $\mathrm{O}_{2}{ }^{-10}$ Hasil penelitian Nurdin (2008), ${ }^{11}$ menunjukkan bahwa klorofilin dosis $3,34 \mathrm{mg} / 200 \mathrm{~g}$ tikus dari ekstrak daun cincau berpengaruh pada profil lipid tikus hiperkolesterolemia. Penelitian oleh Fathin (2010), ${ }^{12}$ menunjukkan bahwa dosis $1,8 \mathrm{mg} / 200 \mathrm{~g}$ pada tikus dapat menurunkan kadar total kolesterol darah. Penelitian ini bertujuan untuk mengetahui pengaruh klorofilin terhadap kadar NO dan kadar MDA pada tikus hiperkolesterolemia.

\section{METODE DAN BAHAN}

Penelitian ini termasuk eksperimental murni dengan rancangan post test only randomized control group design. ${ }^{16}$ Dua puluh empat tikus Sprague Dawley jantan berumur 8 minggu dibagi secara acak menjadi 4 kelompok, yaitu kelompok kontrol teknik (K1) diberi pakan standar dan tanpa perlakuan. Kelompok kontrol negatif (K2) diinduksi hiperkolesterolemia tanpa perlakuan; kelompok perlakuan 1 (P1) diinduksi hiperkolesterolemia dengan perlakuan klorofilin dosis $1,8 \mathrm{mg} / 200 \mathrm{~g} \mathrm{BB} / \mathrm{hari}$; kelompok perlakuan 2 (P2) diinduksi hiperkolesterolemia dengan perlakuan klorofilin dosis 3,34 mg/200 g BB/hari.

Induksi hiperkolesterolemia dengan pemberian lemak babi $2 \mathrm{ml} /$ hari (10\% dari pakan sehari $20 \mathrm{~g}$ ) melalui sonde selama 14 hari yang kemudian dilanjutkan hingga akhir penelitian. Klorofilin dilarutkan dalam air sebanyak $1 \mathrm{ml}$ diberikan melalui sonde selama 21 hari. Induksi hiperkolesterolemia dan pemberian klorofilin diberikan di pagi hari.

Pengambilan sampel darah melalui pembuluh darah mata (plexus reorbitalis). Darah dipisahkan menjadi serum menggunakan alat sentrifus. Variabel yang diukur adalah kadar NO plasma dengan reaksi Griess, kadar MDA plasma dengan metode TBARS, sedangkan kadar kolesterol total dengan CHOD-PAP.

Pemeliharaan hewan coba dan pemeriksaan kadar kolesterol total dan MDA plasma dilakukan di Pusat Studi Pangan dan Gizi UGM, sedangkan pemeriksaan kadar NO plasma di Laboratorium Penelitian dan Pengujian Terpadu (LPPT) UGM, Yogyakarta. Penelitian dilakukan setelah memperoleh dengan Ethical Clearance dari Komisi Etik Penelitian Kesehatan (KEPK) FK UNDIP/RSUP dr. Kariadi No. 018/EC/FK/RSDK/2014 tertanggal 20 Januari 2014.

Data kadar MDA plasma dianalisis menggunakan uji One Way Anova yang dilanjutkan dengan Post hoc LSD , sedangkan data kadar NO plasma menggunakan uji Kruskall Wallis. ${ }^{14}$ Adanya perbedaan ditemukan jika nilai $\mathrm{p}<0,05$, analisa dilakukan dengan nilai derajat kemaknaan 0,05.

\section{HASIL}

\section{Berat Badan Tikus Selama Per cobaan}

Berat badan tikus di semua kelompok mengalami peningkatan selama penelitian. Pada awal adaptasi, tidak terdapat perbedaan berat badan antara kelompok dengan nilai $p=0,978(p>0,05)$ yang berarti bahwa tikus yang digunakan memiliki kondisi dan karakteristik berat badan yang homogen pada awal penelitian (gambar 1). 
Pada akhir penelitian, kenaikan berat badan pada kelompok K2 lebih tinggi daripada kedua kelompok perlakuan secara signifikan masing-masing yaitu $\mathrm{p}=0,041(\mathrm{P} 1) \quad$ dan $\mathrm{p}=0,23(\mathrm{P} 2), \quad(\mathrm{p}<0,05)$, sedangkan berat badan antara kelompok perlakuan (P1 dan $\mathrm{P} 2)$ tidak berbeda dengan nilai $\mathrm{p}=0,780(\mathrm{p}>0,05)$ (gambar $1)$.

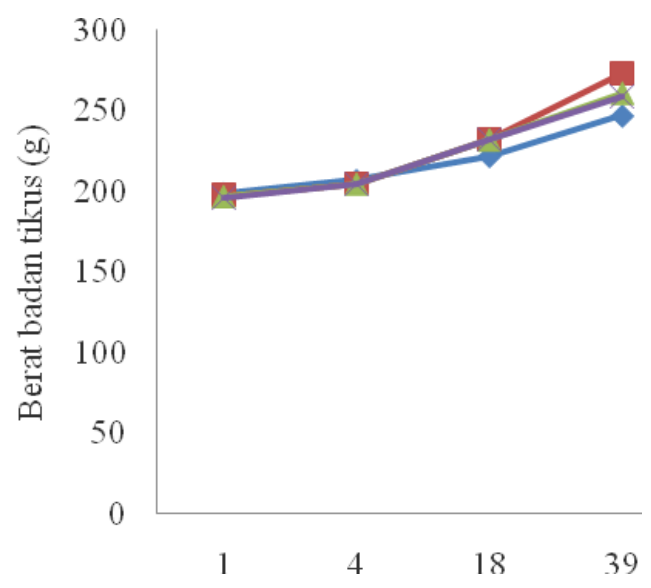

Gambar 1. Diagram perubahi Han berat badan tikus selama percobaan.

Ket : $\nabla=\mathrm{K} 1, \boldsymbol{\square}=\mathrm{K} 2, \Delta=\mathrm{P} 1$ dan $X=\mathrm{P} 2$

\section{Kadar Kolesterol Total Darah Tikus Selama Percobaan}

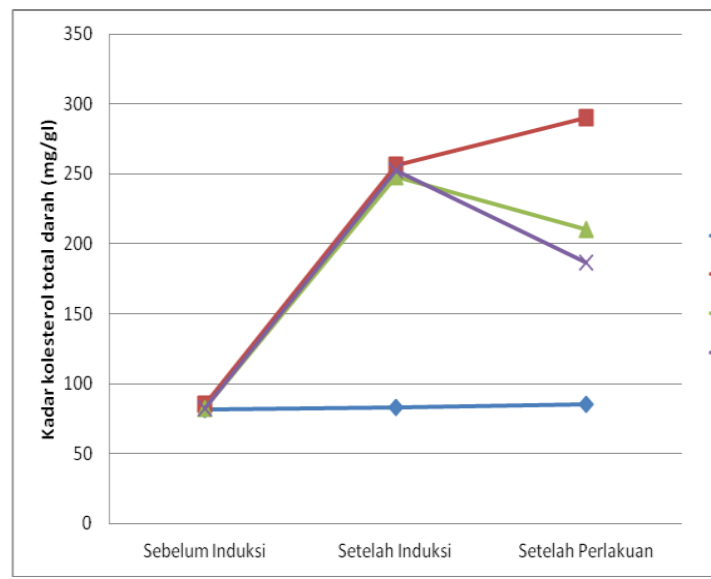

Gambar 2. Diagram perubahan kadar kolesterol total darah tikus selama percobaan

Ket : $>=\mathrm{K} 1, \boldsymbol{\square}=\mathrm{K} 2, \Delta=\mathrm{P} 1$ dan $X=\mathrm{P} 2$

Kadar kolesterol total darah di awal penelitian antara kelompok menunjukkan tidak adanya perbedaan dengan nilai $\mathrm{p}=0,726(\mathrm{p}>0,05)$ yang berarti antara kelompok memiliki karakteristik kadar kolesterol total darah yang homogen (gambar 2). Kenaikan kadar kolesterol total darah terjadi pada ketiga kelompok setelah diinduksi hiperkolestrolemia. Di akhir penelitian, kadar kolesterol total darah pada kelompok K2 terus meningkat, sedangkan kelompok perlakuan mengalami penurunan. Kelompok P2 memiliki kadar kolesterol total darah lebih rendah dibanding P2 $(\mathrm{p}=0,0001)$.

\section{Pengaruh Klorofilin Kadar Nitric Oxide (NO) plasma}

Hasil penelitian menunjukkan rerata kadar $\mathrm{NO}$ plasma tertinggi pada kelompok K2 yaitu $0,224 \pm 0,001 \mu \mathrm{M}$, sedangkan terendah pada kelompok P2 yaitu $0,203 \pm 0,015 \mu \mathrm{M}$. Uji beda yang dilakukan menunjukkan bahwa tidak ada perbedaan kadar NO plasma di antara kelompok penelitian $(\mathrm{p}=0,018)$. Hal tersebut dapat disimpulkan bahwa tidak ada pengaruh pemberian klorofilin terhadap kadar NO plasma pada tikus hiperkolesterolemia (tabel 1).

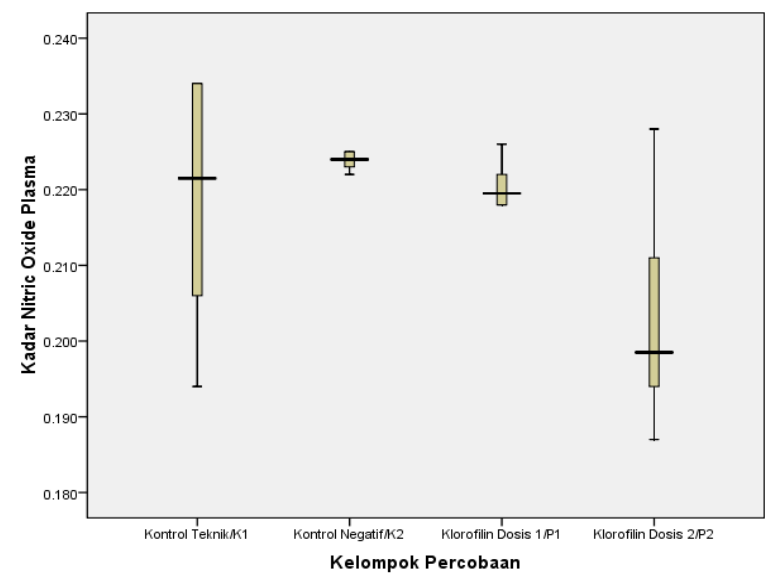

Gambar 3. Diagram kadar NO plasma tikus di akhir percobaan

\section{Pengaruh Klorofilin Kadar Malondialdehyde (MDA) plasma}

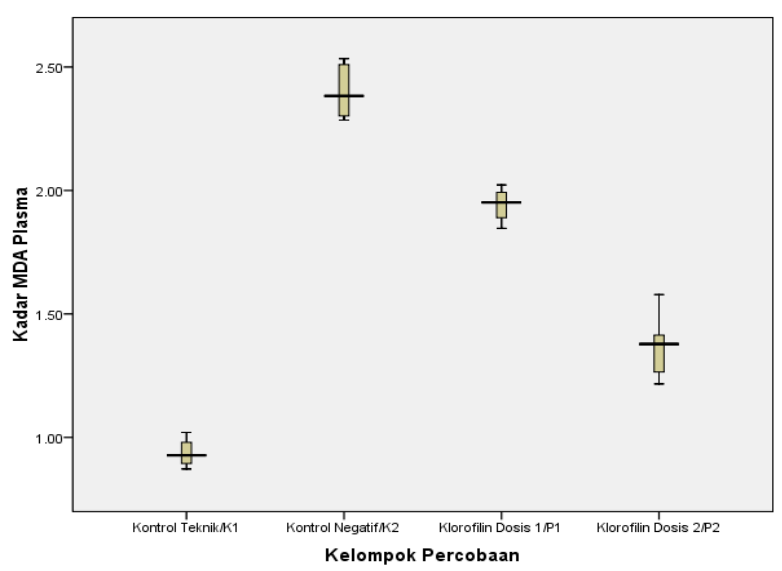

Gambar 4. Diagram kadar MDA plasma tikus di akhir percobaan 
Pada akhir penelitian kelompok P2 memiliki kadar MDA terendah di antara kelompok perlakuan yaitu $1,37 \pm 0,13 \mathrm{nmol} / \mathrm{ml}$ atau $57 \%$ lebih rendah daripada kelompok K2, namun masih lebih tinggi dibanding kelompok K1 yaitu $0,94 \pm 0,05 \mathrm{nmol} / \mathrm{ml}$. Uji beda yang dilakukan menunjukkan bahwa terdapat perbedaan kadar MDA plasma di antara kelompok penelitian. Hal ini berarti ada pengaruh pemberian klorofilin terhadap kadar MDA plasma pada tikus hiperkolesterolemia (tabel 1).

Tabel 1. Pengaruh klorofilin terhadap kadar nitric oxide plasma dan kadar malondialdehyde plasma

\begin{tabular}{|c|c|c|c|c|c|}
\hline \multirow{2}{*}{ Parameter } & \multirow{2}{*}{ K1 } & \multicolumn{3}{|c|}{ Kelompok perlakuan } & \multirow[b]{2}{*}{$\mathbf{p}$} \\
\hline & & $\mathrm{K} 2$ & P1 & $\mathrm{P} 2$ & \\
\hline Kadar NO $(\mu \mathrm{M})$ & $0,218 \pm 0,016$ & $0,224 \pm 0,001$ & $0,220 \pm 0,003$ & $0,203 \pm 0,015$ & $0,118^{\mathrm{b}}$ \\
\hline Kadar MDA (nmol/ml) & $0,94 \pm 0,05$ & $2,40 \pm 0,11$ & $1,94 \pm 0,07$ & $1,37 \pm 0,13$ & $0,001^{\mathrm{a}}$ \\
\hline
\end{tabular}

\section{PEMBAHASAN}

Pada penelitian ini induksi hiperkolesterolemia dapat memicu kenaikan berat badan. Pemberian lemak secara terus menerus memicu terjadinya keseimbangan energi positif disebabkan lemak memiliki nilai konversi yang lebih tinggi daripada karbohidrat dan protein $(4 \mathrm{kkal} / \mathrm{g}$ ), yaitu $9 \mathrm{kkal} / \mathrm{g}$. Kelebihan asupan energi secara akumulatif menyebabkan menumpuknya jaringan lemak sehingga memacu kenaikan berat badan pada tikus. ${ }^{15}$ Kenaikan berat badan kelompok diinduksi hiperkolesterolemia yang lebih tinggi daripada kelompok kontrol juga ditemukan oleh Yan et al. ${ }^{9}$

Sintesa kolesterol di tubuh prosesnya melalui dua jalur yaitu endogen dan eksogen. Dua pertiganya dipenuhi melalui jalur endogen, sisanya dari eksogen yaitu dari asupan makanan. ${ }^{16}$ Kandungan kolesterol yang tinggi pada lemak babi $(85,17 \mathrm{mg} / 100 \mathrm{~g})$ meningkatkan sintesis kolesterol melalui jalur eksogen. ${ }^{17}$ Sintesis kolesterol juga dipicu dengan adanya asam lemak jenuh, terutama dengan rantai $\mathrm{C}>$ 14. ${ }^{15}$ Asam lemak jenuh memicu sintesa kolesterol, khususnya LDL-kolesterol dalam hati. Asam lemak jenuh juga menurunkan ekspresi reseptor LDL dalam hati sehingga terjadi akumulasi LDL di plasma dan peningkatan pembentukan LDL dari VLDL. ${ }^{16}$ Lemak babi mengandung tinggi asam lemak jenuh, terutama jenis palmitat dan stearat (rantai C>14). ${ }^{18}$

Pada penelitian ini tidak ditemukan perbedaan kadar NO plasma antara kelompok penelitian. Induksi hiperkolesterolemia maupun pemberian perlakuan klorofilin tidak memberikan efek kadar NO plasma dibanding kelompok kontrol teknik. Keadaan tersebut menunjukkan bahwa induksi hiperkolesterolemia yang diberikan tidak memiliki efek terhadap fungsi endotel. Hasil penelitian ini mendukung Lorkowska et al, ${ }^{19}$ tikus hiperkolesterolemia (hipertensi/non-hipertensi) tidak mempengaruhi fungsi endotel dengan mengukur kemampuan dilatasi pembuluh darah. Disfungsi endotel ditemukan hanya pada tikus yang diinduksi diet tinggi fruktosa yang memicu resistensi insulin dan hipertrigliseridemia, ${ }^{20}$ walaupun pada penelitian Garjani et al, ${ }^{21}$ keadaan hiperkolesterolemia dapat memicu adanya disfungsi endotel dengan mengukur kemampuan relaksasi pada pembuluh aorta thoracic.

Superoksida dismustase (SOD) merupakan enzim utama yang berperan menetralkan superoksida $\left(\mathrm{O}_{2}-\right)$ menjadi hidrogen peroksida $\left(\mathrm{H}_{2} \mathrm{O}_{2}\right)$ yang kemudian dikonversi menjadi air oleh katalase (CAT) dan glutation peroksidase (GSH-Px). ${ }^{22}$ Menurut White et $\mathrm{al}^{23}$ aktivitas SOD tidak cukup efektif mengikat $\mathrm{O}_{2}{ }^{-}$ yang meningkat pada keadaan hiperkolesterolemia. Hal tersebut didukung oleh $\mathrm{Wu} \mathrm{JH}$ et al, ${ }^{24}$ bahwa aktivitas SOD tidak membaik meski diberikan senyawa antioksidan. Penurunan kadar NO plasma berkaitan dengan $\mathrm{O}_{2}^{-}$yang kadarnya tergantung aktivitas SOD, namun baik kadar $\mathrm{O}_{2}^{-}$atau aktivitas SOD pada penelitian ini tidak dapat dijelaskan dan menjadi keterbatasan penelitian ini.

Pada penelitian ini, kadar NO terendah justru terdapat di kelompok P2 dan tertinggi kelompok K2, walaupun tidak berbeda signifikan. Kadar NO plasma yang lebih rendah daripada kelompok K1 merupakan tanda menurunnya ketersediaan biologis NO. Pada keadaan hiperkolesterolemia disertai hiperhomosisteinemia disebabkan homosistein merupakan fraksi dari lipoprotein. ${ }^{25}$ Menurut Emsley et $\mathrm{al}^{26}$ pemberian $\mathrm{Cu}^{2+}$ pada keadaan hiperhomosisteinemia memicu penghambatan relaksasi dimediasi NO. Konsentrasi $\mathrm{Cu}^{2+}$ yang tinggi menurunkan kemampuan enzim CAT dan SOD serta mengkatalisis produksi $\mathrm{O}^{2-}$ dan $\mathrm{H}_{2} \mathrm{O}_{2}$ sehingga menyebabkan penurunan produksi $\mathrm{NO}$ endotel. ${ }^{27}$ Konsentrasi $\mathrm{Cu}^{2+}$ yang tinggi juga mengoksidasi LDL yang kemudian memicu peroksidasi lipid sehingga mengganggu fungsi normal sel endotel melalui penurunan kadar $\mathrm{NO}^{28,29}$ Berdasarkan mekanisme tersebut diduga kandungan $\mathrm{Cu}^{2+}$ pada klorofilin mempengaruhi kadar NO plasma.

Hasil penelitian ini menunjukkan bahwa klorofilin berpengaruh terhadap kadar MDA plasma. Hasil ini 
mendukung penelitian Nurdin dkk (2008), ${ }^{11}$ bahwa pemberian klorofilin dari daun cincau dapat menurunkan kadar MDA pada tikus hiperkolesterolemia. Hasil penelitian serupa juga didapatkan oleh Jiangwei M et al (2011), ${ }^{30}$ yang menunjukkan bahwa pemberian antioksidan (ekstrak Astragalus mongholicus) dapat menurunkan kadar MDA pada tikus dengan diet tinggi kolesterol. Keadaan hiperkolesterolemia dapat memicu terjadinya peningkatan stres oksidatif akibat produksi berlebihan dari radikal bebas, diantaranya yaitu $\mathrm{O}_{2}^{-}, \mathrm{NO}^{-}$, radikal hidroksi $\left(\mathrm{OH}^{-}\right)$dan radikal lipid $\left(\mathrm{LOH}^{-}\right) .{ }^{29}$ Peningkatan radikal bebas berpotensi memicu terbentuknya senyawa reaktif oksigen seperti $\mathrm{H}_{2} \mathrm{O}_{2}$ dan senyawa reaktif nitrogen seperti peroksinitrit $\left(\mathrm{ONOO}^{-}\right)$atau senyawa reaktif lain seperti asam hipoklorus (HOCl) ${ }^{31}$ Senyawa reaktif tersebut kemudian bereaksi dan mengoksidasi lipid yang tidak jenuh (PUFA) pada membran sel atau disebut peroksidasi lipid yang kemudian memicu kerusakan membran sel serta komponen di dalam sel. ${ }^{32}$

Antioksidan berperan dalam mempengaruhi reaksi rantai tersebut dengan memindahkan produk intermediet radikal bebas, menghambat agen oksidasi lain. ${ }^{33}$ Pemberian senyawa antioksidan juga berpengaruh meningkatkan aktivitas CAT dan GSHPx yang berfungsi dalam konversi $\mathrm{H}_{2} \mathrm{O}_{2}$ menjadi air, $\mathrm{H}_{2} \mathrm{O}_{2}$ diketahui juga senyawa reaktif yang dapat memicu peroksidasi lipid. ${ }^{24}$

Salah satu peran klorofilin yang sangat penting adalah sebagai anti oksidan. Secara in vitro, klorofilin melindungi sel dari stres oksidatif dengan menangkap Reactive Oxygen Species (ROS) yang terbentuk, ${ }^{33}$ khususnya senyawa yang mengandung singlet oxygen seperti $\mathrm{OH}^{-}, \mathrm{O}_{2}{ }^{-}$dan ${ }^{1} \mathrm{O}_{2} .{ }^{10}$ yang kemudian membentuk senyawa kloroperoksi radikal yang mencegah adanya peroksidasi lipid. Klorofilin juga berpengaruh efektif mencegah peroksidasi lipid dalam keadaan enzim SOD tidak aktif dan penurunan GSH-Px. ${ }^{22}$

\section{SIMPULAN}

Pemberian klorofilin tidak memberikan pengaruh pada kadar NO plasma pada tikus hiperkolesterolemia. Pemberian klorofilin dosis 3,34 mg/200 g BB/hari memberikan pengaruh kadar MDA plasma yang lebih rendah dibanding kelompok lain yang hiperkolesterolemia.

\section{SARAN}

Perlu penelitian lebih lanjut dengan mengukur kadar $\mathrm{O}_{2}^{-}$atau aktivitas SOD dan pemeriksaan fungsi endotel lain seperti kemampuan relaksasi endotel.

\section{DAFTAR PUSTAKA}

1. Amin KA, Abd El-Twab TM. Oxidative markers, nitric oxide and homocysteine ateration in hypercholesterolemic rats: role of atorvastatine and cinnamon. Int J Clin Exp Med. 2009; 2:25465.

2. Feron O, Dessy C, Moniotte S, Desager JP, Balligand JL. Hypercholesterolemia decreases nitric oxide production by promoting the interaction of caveolin and endothelial nitric oxide synthase. Journal of Clinical Investigation. 1999; 103:897-905

3. Carr AC, McCall MR, Frei B. Oxidation of LDL myeloperoxidase and reactive nitrogen species : reaction pathways and antioxidant protection. Arterioscler Thromb Vasc Biol. 2000; 20:171623.

4. Davignon J, Ganz P. Role of endothelial dysfunction in atherosclerosis. J. American Heart Association. 2004; 109(Suppl III):27-32.

5. Sardo MA et al. Effect of atorvastatin treatment on Sicam-1 and plasma nitric oxide levels in hypercholesterolemic subject. Clin Appl Thromb Hemost. 2002; 8(3):257-63.

6. Kawashima S and Yokohama M. Dysfunction of endothelial nitric oxide synthase and atherosclerosis. Journal of The American Heart Association. 2004; 24: 998-1005.

7. Utami DFR. Peroksidasi lipid pada tikus hiperkolesterolemia selama pemberian ekstrak kulit batang mahoni (Swietenia macrophylla) [Sarjana Skripsi]. Bogor: Institut Pertanian Bogor:2010.

8. Nielsen F, Mikkelsen BB, Nielsen JB, Andersen HR, Grandjean P. Plasma malondialdehyde as biomarker for oxidative stress: reference interval and effects of life-style factors. Clinical Chemistry, 1997;43(7): 1209-14.

9. Yan Li-Ping, et al. Puerarin decreases serum total cholesterol and enhances thoracic aorta endothelial nitric oxide synthase expression in diet induced hypercholesterolemic rats. Life Sciences, 2006; 79:324-30.

10. Kamat PJ, Boloor KK, Devasagayam TPA. Chloropyllin as an effective antioxidant against membran damage in vitro and ex vivo. Biochimica et Biophysica Acta. 2000; 1487:11327.

11. Nurdin, Khomsan A, Marliyanti SA, Anwar F, Kusharto CM, Agungpriyono DR. Pengaruh pemberian bubuk ekstrak cu-turunan klorofil daun cincau (premna oblongifolia merr) terhadap profil 
lipid darah kelinci. Media Gizi dan Keluarga, 2008; Juli 32(1): 104-14.

12. Fathin K. Pengaruh pemberian klorofil dari tanaman alfalfa (Medicago Sativa) terhadap kadar kolesterol total tikus putih (Rattus norvegicus)[Sarjana Skripsi] Surakarta: Universitas Sebelas Maret; 2010.

13. Campbell DT, Stanley JC. Experimental and quasi-experimental designs for research. Boston: Houghton Mifflin Company; 1966.

14. Dahlan, MS. Statistik untuk kedokteran dan kesehatan. Jakarta: Salemba Medika; 2011.

15. Gropper, SS, Smith JL, Groff JL. Advanced nutrition and human metabolism. Wadsworth: Wadsworth Cengange Learning; 2009.

16. Murray RK, Granner DK, Mayes PA, Rodwell VW (Ed.). Biokimia Harper: Alih bahasa Andri Hartono. Jakarta:EGC; 2001.

17. Tobing SWL. Perbandingan kualitas karkas dan daging antara babi peliharaan dengan babi hutan. [Master Tesis]. Padang: Universitas Andalas; 2012.

18. Buettner R et al. 2006. Defining High-Fat Diet Models: Metabolic and Molecular Effect of Different Fat Types. Journal of Moleculer Endocrinology, 36:485-501.

19. Lorkwoska B et al. Hypercholesterolemia does not alter endothelial function in spontaneously hipertensive rats. The Journal of Pharmacology and Experimental Therapeutics. 2006; 317: 101926.

20. Bartus $M$ et al. 2005. Hypertriglyceridemia but not Hypercholesterolemia Induces Endothelial Dysfunction in The Rat. Pharmacological Report, 57(Suppl): 127-37.

21. Garjani A, Azarmy Y, Zakheri A, Akbari NA, Andalib S, Maleki-Dijazi N. Vascular dysfunction in short-term hypercholesterolemia despite the absence of atherosclerotic lesion. Journal of Cardiovasculer and Thoracic Research. 2011; 3:73-7.

22. Devasagayam TPA, Tilak JC, Boloor KK, Sane KS, Ghaskadbi SS, Lele RD. Free radical and antioxidants in human health: Current status and future prospects. Journal of Association of Physicians of India. 2004; 52:794-804.
23. White CR et al. Superoxide and peroxinitrite in atherosclerosis. Proc. Natl. Acad. Sci. USA. 1994; 91:1044-8.

24. $\mathrm{Wu} \mathrm{JH}$, et al. Suppresion of diet-induced hypercholesterolemia by turtle jelly, a traditional chinese functional food, in rats. Evidence-Based Complementary and Altervative Medicine, 2012: $15 \mathrm{p}$.

25. Olszewski AJ and McCully KS. Homocysteine content of lipoprotein in hypercholesterolemia. Science Direct, 1991; 91:257-4.

26. Emsley AM, Jeremy JY, Gomes GN, Angelini GD, Plane F. Investigation of the inhibitory effects of homocystein and copper on nitric oxidemediated relaxation of rat isolated aorta. British Journal of Pharmacology. 1999; 126:1034-40.

27. Huck D, Thuraisingham RC, Raftery MJ, Yaqoob MM. Homocystein induced impairment of nitric oxide-dependent vasorelaxation is reversible by the superoxida dismustase mimetic tempol. Nephrol Dial Transplant. 2004 ; 19:1999-2005.

28. Filipe $\mathrm{P}$ et al. Anti- and Pro-oxidant Effects of Quercetin in Cpper-Induced Low Density Lipoprotein Oxidation. European Journal of Biochemistry. 2004; 271:1991-99.

29. Stapleton PA, Goodwill AG, James EM, Brock RW, Frisbee JC. Hypercholesterolemia and Microvasculer Dysfunction: Interventional Strategies. Journal of Inflammation, 2010; 7:54.

30. Jiangwei M, Zengyong Q, Xia X. Aqueos extract of astragalus mongholicus ameliorates high cholesterol diet induced oxidative injury in experimental rats model. Journal of Medicinal Plants Research. 2011; 5:855-58.

31. Aher VD, Wahi A, Pawdey AM, Sonawane A. Antioxidants as immunomodulator: an expanding reseach avenue. International Journal of Current Pharmaceutical Research. 2011; 3(1):8-10.

32. Cai H, Harrison DG. Endothelium dysfunction in cardiovascular diseases: the role of oxidant stress. Journal of The American Heart Association. 2000; 87:840-44.

33. Kumar SS, Shankar B, Sainis KB. Effect of chlorohyllin againts oxidative stress in splenic lymphocytes in vitro and in vivo. Biochimia et Biophysica Acta. 2004; 1672: 100-11. 